эффективность после завершения вакцинации превышает 95\% [5].

Гепатит В является приоритетной проблемой здравоохранения всего мира, что связано с высокой инфицированностью населения вирусом, приводящей к тяжелейшим последствиям. Единственной, эффективной мерой профилактики гепатита В и экономический выгодной является иммунизация населения. Развитие иммунопрофилактики на современном этапе требует не только тщательного научного обоснования системы эпидемиологического надзора, но и детального экономического затратно - выигрышного анализа для определения оптимальных программ и тактики вакцинации.

\section{Список литературы}

1.Beutels P, Edmunds WJ, Antonanzas F, et al Economic evaluation of vaccination programmes: a consensus statement focusing on viral hepatitis// Pharmacoeconomics 2002; 20: 1-7
2.EASL International Consensus Conference on Hepatitis B//Journal of Hepatology 38. 2003. 533-540.

3. Gerlich WH, Thornssen A. Terminology, structure, and laboratory diagnosis of hepatitis viruses. Oxford Textbook of Clinical Hepatology. 2001:537565.

4.Ahn YO. Strategy for vaccination against hepatitis B in areas with high endemicity: focus on Корея. Gut 1996; 38: S63-S66.

5. World Health Organization. Hepatitis B: World Health Organization Fact Sheet 204.2000.

6. Adibi P, Ghassemian R, Alavian SM, et al. Effectiveness of hepatitis $\mathrm{B}$ vaccination in children of chronic hepatitis B mothers// Saudi Med J 2004; 25: 1414-18.

7.Экономическая эффективность вакцинопрофилактики//Мет. указания МУ 3.31878 04, M., 2007г.

8.Beutels P, Edmunds WJ, Antonanzas F, et al Economic evaluation of vaccination programmes: a consensus statement focusing on viral hepatitis// Pharmacoeconomics 2002; 20: 1-7

\title{
IMPROVEMENT OF METHODS OF ALVEOPLASTY OF ANTERIOR UPPER JAW IN CASE OF ATROPHY
}

DOI: $\underline{\text { 10.31618/ESU.2413-9335.2020.3.73.665 }}$

Pulatova Shakhzoda Karimovna

Assistant

Kambarova Shakhnoza Alixuseynovna

Assistant

Bukhara State medical institute

Chair of Surgical dentistry

\section{СОВЕРШЕНСТВОВАНИЕ МЕТОДОВ АЛЬВЕОЛОПЛАСТИКИ ФРОНТАЛЬНОГО ОТДЕЛА ВЕРХНЕЙ ЧЕЛЮСТИ ПРИ ЕГО АТРОФИИ}

\author{
Пулатова Шахзода Каримовна \\ Ассистент \\ Камбарова Шахноза Алихусейновна \\ Асссистент \\ Бухарский Государственный медицинский институт \\ Кафедра хирургической стоматологии
}

\section{RESUME}

In article there are facts of 60 patients' research at the age from 35 to 55 with particular atrophy of frontal department of alveolar processof upper jaw with the aim of elimination of this bone tissue defect and carrying out of subsequent dental implantation was used contemporary osteoplastic tissue 'Bio-oss'. High clinic and esthetic efficacy of combination with high safety profile tell about necessity of wider usage bone substitute "'Bio-oss" in surgical practice.

\section{РЕЗЮМЕ}

В статье приведены данные исследования 60 пациентов в возрасте от 37 до 55 лет с атрофией фронтального отдела альвеолярного отростка верхней челюсти. С целью устранения данного дефекта костной ткани и проведения последующей дентальной имплантации применён современный остеопластический материал «Bio-oss». Высокая клиническая и эстетическая эффективность сочетания с высоким профилем безопасности говорят о необходимости более широкого применения костного заменителя «Bio-oss» в хирургической практике.

Key words: secondary adentia of alveolar process atrophy osteoplastic tissue, dental implantation, alvioloplasty.

Ключевые слова: вторичная адентия, атрофия альвеолярного отростка, остеопластический материал, дентальная имплантация, альвеолопластика.

Introduction: Despite the considerable improvement of diagnostic, surgical and restoration methods used in dentistry, there continues to be an increase in the number of patients with tooth loss not 
only among the elderly due to the increase in life expectancy, but also among persons of working age (Robustova T.G. 2003; Losev F.F., 2007; Ivanov S.J., 2009; Proussaefs P., Lozada J., 2005; Balshi S.F., 2007; Fu J.-H., Wang H.-L., 2011). Studies carried out by various authors prove the high medical and social significance of this pathology. Aesthetic requirements are no less important factors than function, especially in the frontal part of the upper jaw when there is a high smile line (Shmidseder J, 2004). There are different surgical methods developed by a number of authors to compensate for the lost bone tissue of the alveolar ridge in the frontal part of the upper jaw. It is established that the needs in full removable artificial limbs are 24.6 on 1000 surveyed (Kalinin A.A., 2006), and at persons aged from 35 up to 44 years in $91.6 \%$ of cases one tooth is extracted at least (Iolov TS. V, 2001).

The purpose: Increase the effectiveness of surgical methods of alveoloplasty in patients with bone deficiency of the alveolar ridge in the frontal part of the upper jaw by using osteoplastic materials.

Materials and research methods: Study was carried out on the basis of the Department of maxillofacial surgery and orthopedic dentistry of the Bukhara State Medical Institute. Under our supervision were patients with partial tooth loss and bone resorption of the frontal alveolar process of the upper jaw (APUJ), who were shown rehabilitation using orthopedic structures fixed on dental implants. The subject of our study was the complex surgical treatment of the pronounced atrophy of the frontal department of the APUJ as a preliminary stage before the dental implantation. The object of observation is patients with partial absence of teeth and insufficient amount of bone tissue in the area of the frontal part of the dental row.

Over the course of 2017 - 2019, 60 patients aged 37 to 55 years were examined who had partial atrophy of the frontal APUJ. Some patients (30 people) went to the clinic to repair lost teeth by dental implantation. After a clinical X-ray examination, it was found that the pronounced atrophy (both in height and width) of bone tissue of the frontal part of the alveolar process creates significant difficulties for the installation of dental implants and, accordingly, the creation of an orthopedic structure supported by implants.

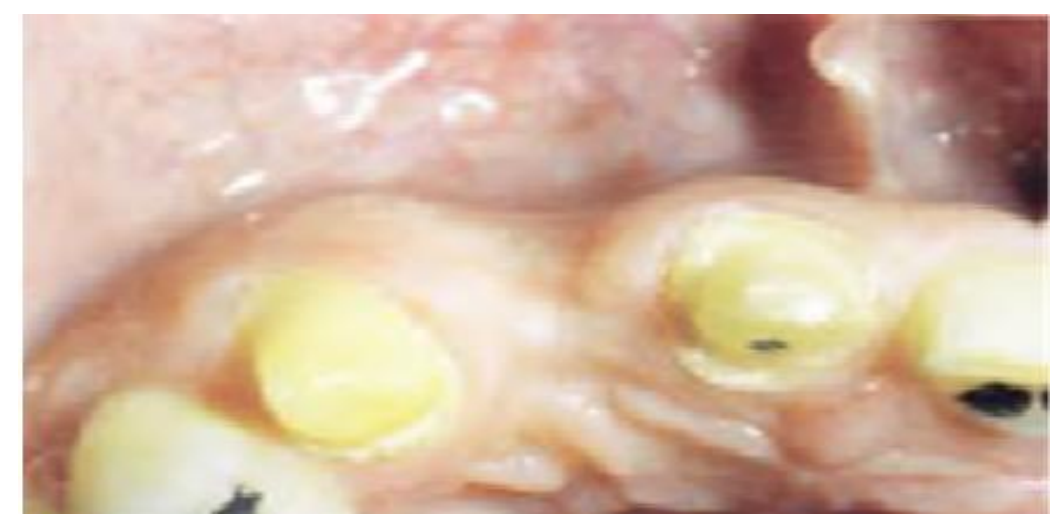

1-Pic. Bone deficiency in the buccal-temporal plane at normal bone edge thoracic in the apical-coronal plane.

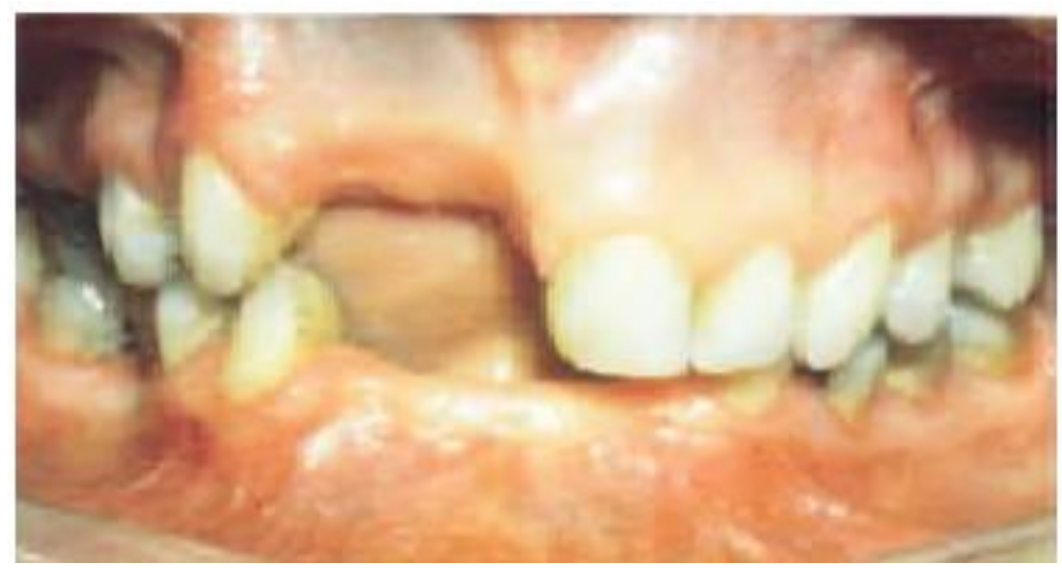

2-Pic. Bone deficiency in the apical-coronal plane at normal bone edge thoracic in the cheek-tongue plane. 


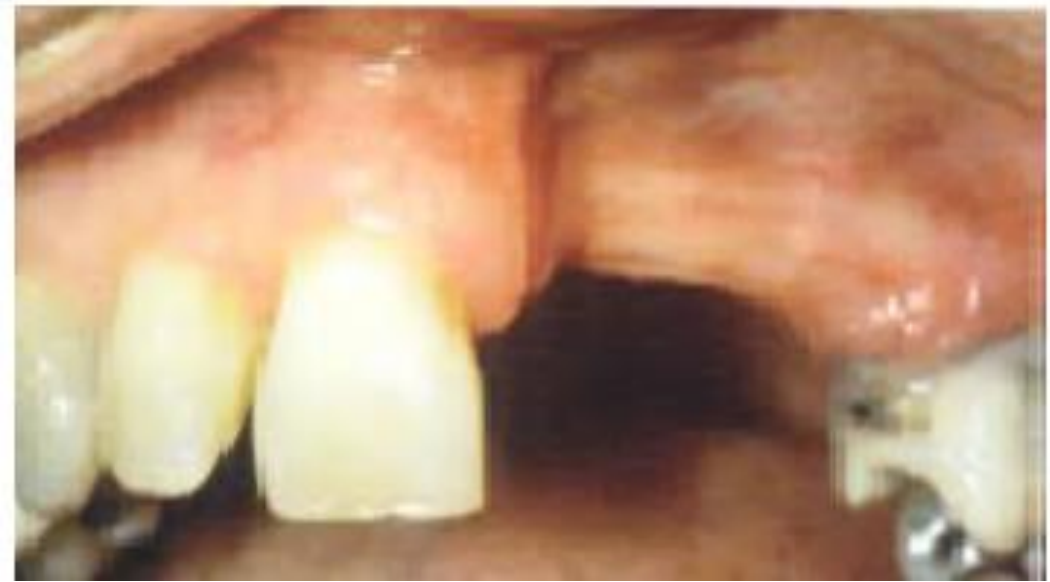

3- Pic. Combination of cheek-tongue and apical-coronal tissue deficiency leading to loss of normal skinny and bone edge widths.

For optimal implant positioning, 30 patients were shown to perform reconstructive surgery to increase the height and width of the frontal APUJ. The remaining patients - 30 people, who made up the main group, expressed a desire to restore the dental row by traditional methods with the help of bridge-shaped and semi-mobile prostheses.

According to the planned treatment plan, all patients were divided into 2 groups: basic and control.

I is the main group $(n=30)$. This group included patients with a pronounced bone defect of the frontal APUJ both in height and width, to eliminate which a volumetric reconstruction was shown. In order to eliminate bone atrophy and the shape of the alveolar ridge, it is planned to use the method developed by us to introduce the bone substitute "Bio-oss" containing hydroxyapatite and $\beta$-tricalcium phosphate. For this purpose two vertical incisions are made on alveolar process from vestibular side within toothless atrophic section to transition fold and horizontal incision along its ridge is connected to them. Then mucosteal flaps are peeled off by means of a splitter and "Bio-oss" is introduced as powder. Subsequently, after 3-4 months, after preliminary X-ray control, dental implantation was carried out to patients.

II - control group $(n=30)$ - patients who used bridge prosthesis in 20 patients and semi-dental prostheses in 10 patients to recover the denture defect. After prosthetics, the most optimal aesthetic and functional result was obtained in patients of the main group, while in patients of the control group after prosthetics with bridge and semi-large prostheses due to the preserved site of atrophy cosmetic results did not meet the required requirements.

Results and discussion: - Dental implantation in pronounced APUJ atrophy is impossible without restoration of bone tissue parameters. On the basis of data obtained from 120 literary sources, the need for bone-plastic operations in patients before dental implantation is $26 \%$ to $55 \%$.

- Modern effective methods of reconstruction of APUJ have been developed and introduced into clinical practice, eliminating bone defects of various types and degrees of atrophy, localization and length. The result of these methods is the formation of full bone tissue, which allows carrying out adequate dental rehabilitation of the patient with the help of orthopedic structures fixed on dental implants.

- The evaluation of the quality of newly formed bone tissue in the area of APUJ reconstruction 6 to 8 months after surgery, based on the results of histomorphometric examination and computed tomography, indicates that the formed bone tissue is a mature bone of sufficient density capable of with standing the occlusion load exerted on the dental implant integrated into the bone plastic zone.

- The introduction of developed methods of elimination of APUJ atrophy into clinical practice expands the indications for dental implantation in patients with partial or complete tooth loss with insufficient bone tissue and after treatment contributes to a significant improvement in the quality of life and dental health of patients.

\section{References:}

1. Adonina O.V. Clinico-X-ray evaluation of the results of intraossal implantation operation with lifting of the bottom of maxillary sinuses: dis.cand.med.sc.: 14.00.21/Adonina Oxana Vitalevna. - M., 2004. - 147 p.

2. Alimsky A.V. To the issue of providing orthopedic dental care to persons of old age with complete absence of teeth living in Moscow and Moscow region/A.V. Alimsky, V.S. Vusati, V.F. Prikules//Dentistry. - 2004. - Vol. 83, № 4. - P. 72.

3. Alfaro F.E., Bone plastic in dental implantology. Description of the techniques and their clinical application (F.E. Alfaro; publisher A. Ostrovsky; E. Hanin, R. Kononov. - Moscow: Azbuka, 2006. - 235 p. - ISBN 5-902693-14-4.

4. Amhadova M.A. Risk factors and algorithm for prediction of postoperative complications with increase of bone tissue volume in the area of maxillary sinus bottom/M.A. Amhadova, A.A. Nikitin, A.M. Sipkin//Dental journal. - 2009. - № 2. - S. 182-184.

5. Anikin Yu. M. Construction and properties of bone structures/Yu.M. Anikin, L.L. Kolesnikov. - M., 1993. - $127 \mathrm{p}$.

6. Arkhipova. A. V.. Method for prevention of perforations of maxillary sinus mucosa in sinus 
lifting/a.v. archipelago//dentistry. - 2012. - № 6. - C. 45-47.

7. Bazikyan E.A., Restoration of the alveolar ridge of the upper jaw in the distal departments for the installation of dental implants/E.A. Bazikyan, B.S. Smbatyan//Clinical dentistry. 2008. - No. 2. - Page 411.

8. Bazikyan E.A., Endodonto-endoossal implantation, modern aspects and ways of improvement/E.A. Bazikyan, M.V. Lomakin, A.V. Mitronin//Russian Journal of Dental Implantology. 2005. № 1/2 (9/10). - p. 86-94.

9. Besrukov V.M., Subperiostal implantation as a method of surgical rehabilitation of patients with significant atrophy of jaws/V.M. Besrukov, A.A. Kulakov//Russian Journal of Dental Implantology. 2003. - № 1. - p. 60-64.
10. Belous A.M. Some results of research on repair bone regeneration/A.M. Belous, E.J. Pankov//Mechanisms of bone tissue regeneration. - M.: Medicine, 2002. - S. 284-294.

11. Belser U., Statement by a panel of experts participating in a conciliation conference on clinical aspects of dental implantology with respect to aesthetics/W. Belser, D. Buser, F. Higginbottom; Per. A. Ostrovsky//PERIO Ai Kew. - 2006. 7. - p. 14-16. ISSN 1816-8862.

12. Bolonkin V.P. Application of lyophilized alloplast material for bone plastic at different degree of alveolar process atrophy and low location of the maxillar sinus. Single-stage implantation/V.P. Bolonkin, P.A. Fishakov, I.V. Bolonkin//Russian Journal of Dental Implantology. - 2005. - № 3/4 (11/12). - p. 48-56.

\title{
КОД УДК 617-089.844
}

\section{COMBINED EXPOSURE DIRECT ELECTRICAL STIMULATION AND MECHANOTHERAPY USING "LOKOMAT" SOFTWARE OF PATIENTS WITH NEUROLOGICAL DEFICIT: A REPORT OF THREE PATIENTS}

\author{
DOI: $10.31618 /$ ESU.2413-9335.2020.3.73.667 \\ Meshcheriagina I.A. \\ Federal State Budgetary Institution \\ "National Ilizarov Medical Research Center \\ for Traumatology and Ortopedics" \\ of Ministry of Healthcare, the Russian Federation \\ Address: 6, M.Ulyanova street, Kurgan, 640014, Russia \\ International Office: \\ Tel: +7 (3522) 45-47-58. \\ Communication in English, French, German, Japanese \\ Official web-site: $\underline{w w w . i l i z a r o v . r u}$
}

Address for correspondence:

Proletarskaia Str., 44. Apt. 10. Kurgan. 640000. Russia.

\begin{abstract}
A technique of complex mechanotherapy exposure in patients with neurological deficit has been proposed using "Lokomat" device combined with epidural proximal stimulation of spinal cord and epineural one of the damaged nerve trunk with implanted electrodes together with distal electrical stimulation of the muscle groups of the autonomous areas with epicutaneous leads to potentiate electrical stimulation. The technique has been used in treatment of three patients, the advantages of simultaneous performing mechanotherapy and electrical stimulation have been revealed.

Keywords: electrical stimulation, mechanotherapy, neurological deficit, effect potentiation.

\section{Introduction}

Myelopathy and neuropathy of different genesis is accompanied by marked motor disorders, pain, change in muscular tension in most cases ${ }^{1,2}$. Currently there is no unified algorithm of treatment and rehabilitation measures for patients with such manifestations ${ }^{3,4}$. The techniques of neuromodulation including different variants of electrical stimulation are the mainstay of treatment of the patients of this category ${ }^{5,6}$.

In the cases presented electrical stimulation is performed simultaneously with exercises using "Lokomat" complex in order to achieve a positive effect. An electrode is placed in the epidural space by closed puncture insertion. As for epineural stimulation, an electrode is placed in the epineural space proximally

electrodes are sutured to the skin. Combined course of temporary electrical stimulation is combined with epicutaneous leads on the lower limbs in the autonomous areas with the amplitude of $30 \mathrm{~mA}$, frequency $-40-60 \mathrm{~Hz}$, and time of exposure -900 seconds. A course of simultaneous complex electrical stimulation with epidural and epineural electrodes is performed postoperatively, which is combined with epicutaneous leads on the lower limbs in the projection of the autonomous areas of the muscles concerned. The course of electrical stimulation is contemporized with imitation of movement. The dynamics of muscle response is evaluated with "Lokomat" integrated software complex. The mean course of treatment is 13 days.
\end{abstract} to the level of the injury of the peripheral nerve. The 